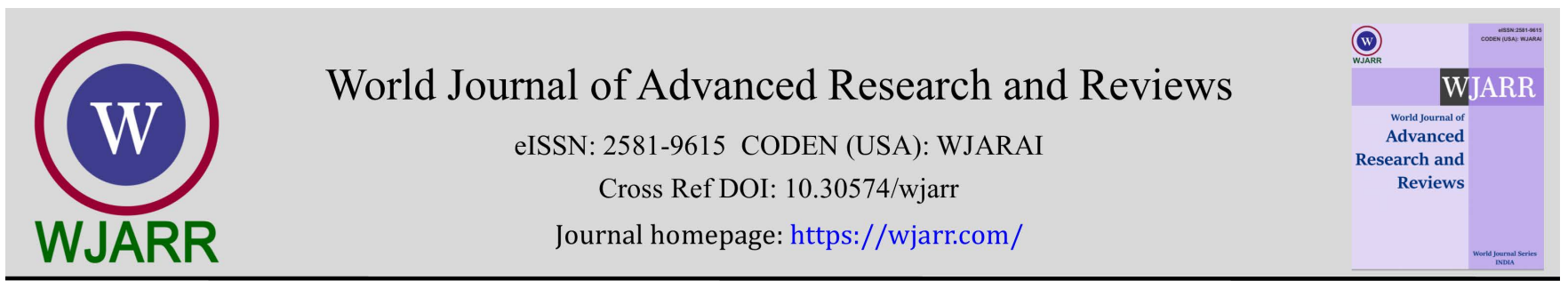

(RESEARCH ARTiClE)

\title{
Physicochemical and heavy metals analysis of Udo Awankwo River in Ikot Ekpene, South-South, Nigeria
}

\author{
Divine Jacob Ottong and Jonathan Okokon Ekanem* \\ Department of Biological Sciences, Ritman University, Ikot Ekpene, Akwa Ibom State, Nigeria.
}

World Journal of Advanced Research and Reviews, 2021, 10(03), 392-398

Publication history: Received on 15 May 2021; revised on 25 June 2021; accepted on 27 June 2021

Article DOI: https://doi.org/10.30574/wjarr.2021.10.3.0282

\begin{abstract}
The physicochemical and heavy metal studies of water samples obtained from Udo Anwankwo River were investigated. Water samples were collected from three different sampling points along the course of the river and analyzed using standard procedures. The physicochemical parameters like the Biochemical Oxygen Demand (BOD) were above the less than $4.0 \mathrm{mg} / \mathrm{l}$ permissible limit by WHO. The temperature ranged from $28.0^{\circ} \mathrm{C}$. to $28.2^{\circ} \mathrm{C}$ while the $\mathrm{pH}$ and electrical conductivity ranged from 7.70 to 8.03 and 16.25 to $33.16 \mu \mathrm{s} / \mathrm{cm}$. All the heavy metals (Nickel, Lead, Cadmium, Chromium and Arsenic) analyzed were above the permissible limit's standard set by WHO for drinking water. The study suggests the need for urgent measures towards the control of pollution and enlightening of the locals on the need for proper disposal of wastes and water treatment before use.
\end{abstract}

Keywords: Physicochemical; Heavy metals; BOD; pH; WHO; Water samples

\section{Introduction}

An aquatic ecosystem is an ecosystem in a body of water. Water is a crucial resource in the ecosystem since it supports life to survive. Safe drinking water is essential to humans and other life forms even though it provides no calories or organic nutrients [1]. The earth ecosystems are held and maintained by water [2]. Water covers about $70.9 \%$ of the earth surface [3].

Fresh water is one of the most important resources crucial for the survival of all the living beings. It is even more important for the human being as they depend upon it for food production, industrial and waste disposal, as well as cultural requirement [4]. Human and ecological use of ground water depends upon ambient water quality. Water quality is affected by a wide range of natural and human influences. The most important of the natural influences are geological, hydrological and climatic, since these affect the quantity and the quality of water available [5]. Their influence is generally greatest when available water quantities are low and maximum use must be made of the limited resource; for example, high salinity is a frequent problem in arid and coastal areas [5]. Although water may be available in adequate quantities, its unsuitable quality limits the uses that can be made of it. Although the natural ecosystem is in harmony with natural water quality, any significant changes to water quality will usually be disruptive to the ecosystem [5].

Wastes such as municipal, industrial and agricultural waste are being disposed into water bodies thereby contaminating it. Biological and chemical contaminants also enter water sources. Rivers as water sources are very important drinking water supply, recreational and sporting activities such swimming, fishing etc [6].

The quality of water is of vital concern for the mankind since it is directly linked with human welfare. Owing to the importance of the river, this study was conducted to ascertain physicochemical and heavy metal status of the water.

*Corresponding author: Ekanem Jonathan Okokon

Department of Biological Sciences, Ritman University, Ikot Ekpene, Akwa Ibom State, Nigeria.

Copyright (C) 2021 Author(s) retain the copyright of this article. This article is published under the terms of the Creative Commons Attribution Liscense 4.0. 


\section{Material and methods}

\subsection{Study area}

Udo Anwankwo River is located beside the popular Akwa Ibom State Polytechnic, Ikot Osurua, Lat 5.160, 7.67 in the raffia city of Ikot Ekpene, Nigeria. It receives input from the old sunshine battery factory and Akwa Ibom State Polytechnic, Ikot Ekpene. Three sampling points were chosen along the course of the River to collect water for analysis. These sampling points were strategically chosen because of the influx of wastewater and/or human activities/influence around the course of the river. The three sampling points lies between the latitudes $5^{\circ} 09^{\prime} 13.9,5^{\circ} 09^{\prime} 41.1,5^{\circ} 09^{\prime} 23.2$ and longitudes $7^{\circ} 38^{\prime} 11.5,7^{\circ} 40^{\prime} 04.3,7^{\circ} 39^{\prime} 27.5$ respectively.

\subsection{Sample collection}

Water samples were collected from three points in pre-cleaned 1 litre capacity plastic bottles and immediately delivered to the Microbiology and Biotechnology Laboratory, Department of Biological Sciences, Ritman University, Ikot Ekpene - Akwa Ibom State, Nigeria in ice packs. The samples were processed immediately. Samples for the heavy metal analysis were acidified with $\mathrm{HNO}_{3}$ to preserve the metal composition.

\subsection{Physicochemical analysis of the water samples}

The water quality parameters which include conductivity and $\mathrm{pH}$ were determined using the conductivity meter and the pH meter respectively. The classical titrimetric method was used for determination of acidity, alkalinity, total hardness, calcium hardness, magnesium hardness, chloride ions and sodium chloride levels of the water samples; while the total solids, total suspended solids and total dissolved solids were determined using the classical gravimetric methods. The spectrophotometric method was used in the determination of the phosphate and sulphate ions. The biochemical oxygen demand (BOD) and chemical oxygen demand (COD) were determined using the standard methods [7].

\subsection{Analysis of Water Samples for Heavy Metals}

Atomic absorption spectrophotometer (AAS) model 939 was used in determining heavy metals following the standard procedures of APHA [8]. Lead, Nickel, Chromium, Cadmium, and Arsenic. Atomic absorption spectrophotometer working principle is based on the sample being aspirated into the acetylene flame and atomized when the light beam of the AAS is directed through the flame into the monochrometer and unto the detector that measures the amount of light absorbed by the atomized element in the flame. Since metals have their own characteristic absorption wavelength, a source lamp composed of that element is used, making the method relatively free from spectral or radiational interferences. The amount of energy of the characteristic wavelength absorbed in the flame is proportional to the concentration of the element in the sample [8].

\section{Results}

\subsection{Physicochemical Properties of Water Samples}

The Physicochemical properties of the water samples at different sampling points are as presented in Table 1.

The temperature of the water at the different sampling points 1,2 and 3 was $28.2^{\circ} \mathrm{C}, 28.0^{\circ} \mathrm{C}$ and $28.1^{\circ} \mathrm{C}$ respectively. The $\mathrm{pH}$ of the water at the three sampling points was 7.75, 7.70 and 8.03 respectively and was slightly alkaline.

The electrical conductivity was higher at sampling point 3 while both the titratable acidity and alkalinity had their highest record at point 1 and point 3 respectively. The biochemical oxygen demand (BOD) and chemical oxygen demand (COD) are as presented in the table. There was slight difference in the BOD at the various sampling points but the COD at sampling point 3 was very low compared to that of point 1 and point 2 . The total suspended solids and dissolved solids ranged from $41.84-56.11 \mathrm{mg} / \mathrm{l}$ and $83.51-91.93 \mathrm{mg} / \mathrm{l}$ respectively. The lowest sulphate concentration was recorded at point 1 , nitrate was at point 2 and chloride at point 3 . The water hardness was between 14.30 and 24.18 representing points 2 and 3 respectively. 
Table 1 Physicochemical properties of the water samples collected from the three sampling points in Udo Anwankwo River

\begin{tabular}{|l|c|c|c|}
\hline \multicolumn{4}{|c|}{ Sampling points } \\
\hline Parameters & Point 1 & Point 2 & Point 3 \\
\hline Temperature $\left({ }^{\circ} \mathrm{C}\right)$ & 28.2 & 28.0 & 28.1 \\
\hline $\mathrm{pH}$ & 7.75 & 7.70 & 8.03 \\
\hline Electrical conductivity $(\mu \mathrm{s} / \mathrm{cm})$ & 16.25 & 21.10 & 33.16 \\
\hline Titratable acidity $(\mathrm{mg} / \mathrm{l})$ & 31.44 & 28.40 & 19.20 \\
\hline Titrable alkalinity $(\mathrm{mg} / \mathrm{l})$ & 20.43 & 15.03 & 21.14 \\
\hline BOD $(\mathrm{mg} / \mathrm{l})$ & 5.19 & 4.33 & 6.45 \\
\hline COD $(\mathrm{mg} / \mathrm{l})$ & 8.87 & 9.60 & 2.60 \\
\hline Suspended solids $(\mathrm{mg} / \mathrm{l})$ & 56.11 & 41.84 & 43.20 \\
\hline Dissolved solids $(\mathrm{mg} / \mathrm{l})$ & 83.51 & 91.93 & 88.12 \\
\hline Sulphate $(\mathrm{mg} / \mathrm{l})$ & 16.02 & 21.67 & 18.00 \\
\hline Nitrate $(\mathrm{mg} / \mathrm{l})$ & 2.65 & 1.05 & 2.55 \\
\hline Chloride $(\mathrm{mg} / \mathrm{l})$ & 12.03 & 16.60 & 7.63 \\
\hline Hardness $(\mathrm{mg} / \mathrm{l})$ & 23.50 & 14.30 & 24.18 \\
\hline
\end{tabular}

KEY: BOD = Biochemical Oxygen Demand, COD = Chemical Oxygen Demand

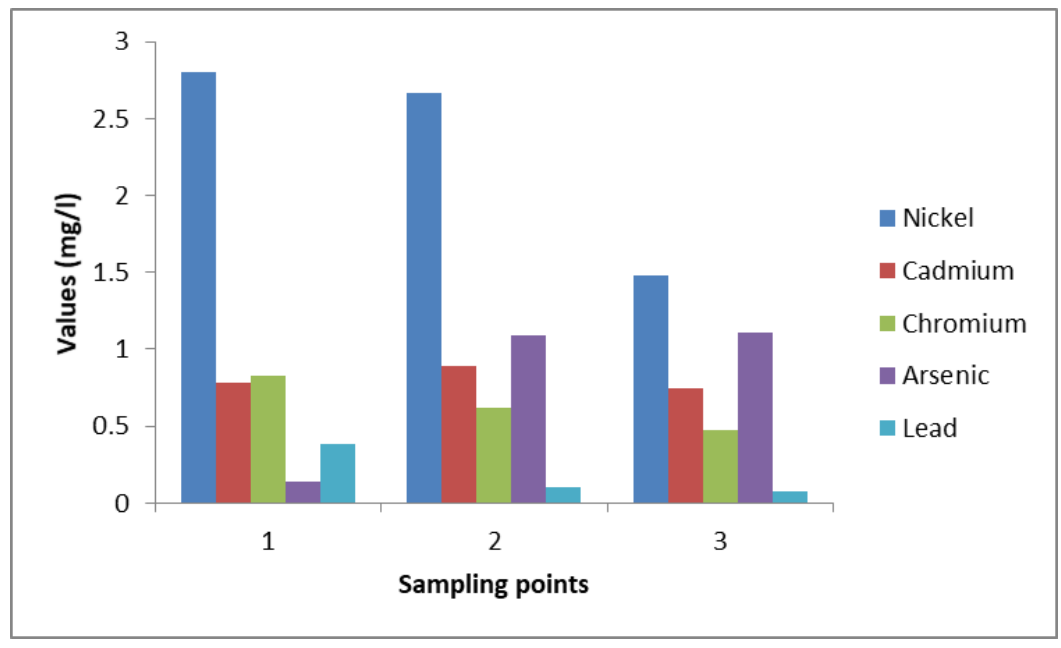

Figure 1 Heavy Metal Levels in the Water Collected at Different Sampling Points

Table 2 Heavy metal levels in the water collected at different sampling points

\begin{tabular}{|l|c|c|c|}
\hline Parameters & Point 1 & Point 2 & Point 3 \\
\hline Nickel, Ni (mg/l) & 2.8 & 2.67 & 1.48 \\
\hline Cadmium, Cd (mg/l) & 0.78 & 0.89 & 0.75 \\
\hline Chromium, Cr (mg/l) & 0.83 & 0.62 & 0.47 \\
\hline Arsenic, As (mg/l) & 0.14 & 1.09 & 1.11 \\
\hline Lead, Pb (mg/l) & 0.38 & 0.1 & 0.08 \\
\hline
\end{tabular}


figure 1and Table 2 shows the heavy metal concentration of the river. The concentration level of Nickel varied between $1.48 \mathrm{mg} / \mathrm{l}$ and $2.80 \mathrm{mg} / \mathrm{l}$, Cadmium was $0.78 \mathrm{mg} / \mathrm{l}, 0.89 \mathrm{mg} / \mathrm{l}$ and $0.75 \mathrm{mg} / \mathrm{l}$ respectively for the three sampling points. Chromium was between $0.47 \mathrm{mg} / \mathrm{l}$ and $0.8 \mathrm{mg} / \mathrm{l} 3$, arsenic varied between $0.14 \mathrm{mg} / \mathrm{l}$ and $1.11 \mathrm{mg} / \mathrm{l}$. Lead had the lowest concentration of all the heavy metals analyzed and varied between $0.08 \mathrm{mg} / \mathrm{l}$ and $0.38 \mathrm{mg} / \mathrm{l}$.

\section{Discussion}

The physicochemical and heavy metal status of Udo Anwankwo River was investigated and the results vary in water quality at different sampling points. Physicochemical parameters are most significant determinant for evaluating the quality of drinking water. The results of the physicochemical analysis of the water samples as presented in Table 1 showed that the $\mathrm{pH}$ values recorded are within the World Health Organization, WHO permissible limit of $6.5-8.5$ and Federal Environmental Protection Agency (FEPA) permissible limit of 6.0 - 9.0. This observation is also similar to the $\mathrm{pH}$ value range of 7.8-8.2 reported in Turkey [9] and Ibadan, Nigeria [10] but lower compared to the range of 7.4 - 10.0 reported from another study in Turkey [11]. The $\mathrm{pH}$ of water is very important in that changes in $\mathrm{pH}$ values may affect the toxicity of microbial poisons in the water [12]. In the present study, pH near neutrality of the water sample poses no health risk to consumers who use the water for cooking, drinking, washing, bathing etc. Acidic pH observed may be an indication of the contamination of the water sample [13].

Temperature varied between $28.0-28.2^{\circ} \mathrm{C}$ which lie within the range of $<32^{\circ} \mathrm{C}$ for safe drinking water [14]. The temperature range observed in this work will discourage the rate of chemical and biochemical reactions, solubility of gases in the water which could impact negativity on the taste and odor of the water at higher temperatures [15]. The present observation is in consonance with the result obtained by Mgbemena NM et.al. [16] who reported that the average temperature was between $28-29^{\circ} \mathrm{C}$.

Total dissolved solids (TDS) comprise inorganic salts and small amount of organic matter that dissolved in water [14]. In the present study, the total dissolved solids (TDS) were found to be between $83.51-91.93 \mathrm{mg} / \mathrm{l}$ in the three sampling points which falls within normal range as described by WHO i.e., $1000 \mathrm{mg} / \mathrm{l}$ for drinking water [14].

The total suspended solids (TSS) value obtained was $41.84-56.11 \mathrm{mg} / \mathrm{l}$ at the sampling points. This was within the normal range as described by WHO for drinking water standards [13]. The suspended solids are insoluble particles that either float on water or are in suspension causing turbidity [17].

In the present study, the total alkalinity of water sample $(15.03-21.14 \mathrm{mg} / \mathrm{l})$ was found to be very low. According to WHO standard, the highest desirable limit (HDL) and maximum permissible limit (MPL) for the total alkalinity is 200$600 \mathrm{mg} / \mathrm{l}$ [18]. The acidity of water sample was found to be very much within the permissible limits [14].

The present study shows that the total hardness of water sample was between $14.3-23.5 \mathrm{mg} / \mathrm{l}$ at the different sampling points. The results are similar to those of Sunday OE,Innocent CM, Shally SC et.al, [19] [20]. The total hardness (the sum of calcium and magnesium ions) of samples were less than $500 \mathrm{mg} / \mathrm{l}$ and within the permissible limit of WHO suggesting that the water is soft and fit for domestic use [21].

The chloride concentration of water was found to be between 7.63 and $16.60 \mathrm{mg} / \mathrm{l}$ which are similar to the results obtained by Okereke VE et.al, Shally SC et.al, [13] [20]. Excessive chloride concentration increases rates of corrosion of metals. Chloride is one of the major anions in water; it is generally associated with sodium. High level of chloride ions may result in an objectionably salty taste [14].

The nitrate content of the water is between $1.05-2.65 \mathrm{mg} / \mathrm{l}$ which is considerably low and poses no health risk to consumers. High Nitrate content in the presence of microbial contamination can lead to cyanosis disease or blue baby syndrome in bottle fed infants [14], thus nitrate levels above $100 \mathrm{mg} / \mathrm{l}$ is not recommended for use in infants. Nitrate is found naturally in the environment and it is an important plant nutrient. The nitrate level observed in this work show that there is less exposure of water to inorganic constituents within the aquiferous material, and this pose no health risk to consumer as the nitrate level is within the standard for drinking water.

Biological Oxygen Demand (BOD) measures the amount of oxygen used by microorganisms, in this case bacterium, to oxidize organic matter present within the samples. Water samples with the BOD less than $4.0 \mathrm{mg} / \mathrm{l}$ are considered clean. From the result in this study, the BOD ranges from $4.33-6.45 \mathrm{mg} / \mathrm{l}$. This means that water is not clean [22].

According to Rajini K et.al, [22], the WHO standard for COD of good quality water is $<10 \mathrm{mg} / \mathrm{l}$. If the COD is higher, it will contain greater number of micro-organisms. COD is a measure of the capacity of water to consume oxygen during the 
decomposition of inorganic chemicals such as nitrate and ammonia. The COD is related to BOD. However, BOD only measures the amount of oxygen consumed by microbial oxidation and is most relevant to water rich in organic matter [23].

The COD of our sample was found to be between $2.60 \mathrm{mg} / \mathrm{l}$ and $9.60 \mathrm{mg} / \mathrm{l}$ at the different sampling points, which is normal. This makes the river water at these sites suitable for domestic purpose [19].

Except at sampling point 1 with $0.38 \mathrm{mg} / \mathrm{l}$, the lead content of the river is within the SON and WHO permissible limits of $0.1 \mathrm{mg} / \mathrm{l}$. this is in agreement with the report of other researchers during similar studies [10] [24] [25] reported a higher level of $3.59 \mathrm{mg} / \mathrm{l}$.

All other heavy metals analyzed like nickel, cadmium, chromium and arsenic were all above the permissible limit's standard set by WHO for drinking water. The high levels of heavy metals recorded in the study can be attributed to a lot of anthropogenic activities that occur in the area such as dredging and the influx of waste and wastewaters into the water body. The implication of this is hazardous to health as those heavy metal's concentration are reported to have severe health consequences. The higher level of Lead as reported in this study may cause health problems like cancer, anaemia etc [19]. The concentration of nickel is above the WHO guideline value of $0.07 \mathrm{mg} / \mathrm{L}$ [14]. The values of Arsenic are above the WHO guideline of $0.01 \mathrm{mg} / \mathrm{L}$ for drinking water and have high potential risk [14]. According to Smith, A. $\mathrm{H}$ et.al, [26], Long term exposure to arsenic can lead to the formation of skin lesions, internal cancers, neurological problems, pulmonary disease, peripheral vascular disease, hypertension and cardiovascular disease and diabetes mellitus.

\section{Conclusion}

Before water can be described as potable, it has to comply with certain physical, chemical and microbiological standards, which are designed to ensure that the water is potable and safe for drinking. Potable and domestic water should be harmless for human health and other domestic uses. No concentration of metal elements or any metal has been reported as being safe, because long term exposure to low concentration is equally harmful. The river water is highly polluted with nickel, lead, arsenic, cadmium, chromium and arsenic as they exceed both the Maximum Acceptable Concentration and the Maximum Permissible Limit of World Health Organization. It can be concluded that water from the entire source is not fit for domestic usage without further processing. As increase in industrialization and population causes increase in living standard, this results in decrease in the quality of water. The water body needs urgent measures to control pollution by controlling human activities such as washing, dredging etc that goes on the river unabated so as to prevent sewage from entering the water body which is the key to avoid bacterial contamination of the water, and thus provide means of safe water for use, thereby protecting the water body.

\section{Compliance with ethical standards}

\section{Acknowledgments}

The authors appreciate the laboratory staff of the Department of Biological Sciences, Ritman University for their immense support and assistance throughout the duration of this research.

\section{Disclosure of conflict of interest}

The authors have declared that no conflict of interest exists.

\section{References}

[1] Mahmud T, Mukharjee SK, Khalil I, Rahman A, Hossen F. Physicochemical and Microbiological analysis of tubewell water from Noakhali district, Bangladesh. World Journal of Microbiology.2016; 3(1): 050-055.

[2] McCartney MP, Acreman MC,Bergkamp G. Freshwater ecosystem management and environmental security. Institute of Hydrology, Wallingford, Oxon, OX10 8BB, UK 2 IUCN, Rue Mauverney 28, 1196 Gland, Switzerland. 1999.

[3] Verplanck PI, Nordstrom DK, Plumlee GS, Wanty RB, Bove DJ, Caine JS. Hydrochemical controls on surface and groundwater chemistry in natural acidic porphyry-related mineralized areas, Southern Rocky Mountains. Chinese Journal of Geochemistry. 2006; 25:231-241. 
[4] Akpoveta OV, Okoh BE, Osakwe SA. "Quality assessment of borehole water used in the vicinities of Benin, Edo State and Agbor, Delta State of Nigeria", Current Research in Chemistry. 2011; 3: 6269.

[5] Bartram J, Balance R. Water Quality Monitoring - A Practical Guide to the Design and Implementation of Freshwater Quality Studies and Monitoring Programmes. In: Microbiological Analyses. UNEP/WHO 1996.

[6] Shanbehzadeh S, Dastjerdi MV, Hassanzadeh AK. Heavy Metals in Water and Sediment: A Case Study of Tembi River. Journal of Environmental Science and Public Health. 2014; 1-5.

[7] APHA.Standard methods for the examination of water and waste water. 2nd Edition. New York: American Public Health Association. 1998; 1120.

[8] APHA. Standard Methods for the examination of Water and Waste Water. 21st Edition., New York: American Public Health Association. 2005; 1498.

[9] Atici T, Obali O, Altindag A, Ahiska S, Aydin D. The accumulation of heavy metals (Cd, Pb, $\mathrm{Hg}, \mathrm{Cr}$ ) and their state in phytoplanktonic algae and zooplanktonic organisms in Beysehir Lake and Mogan Lake, Turkey. African Journal of Biotechnology. 2010; 9:475-487.

[10] Adekanmbi AO, Falodun OI. Physicochemical, microbiological and heavy metal studies on water samples and bacteria obtained from Dandaru River in Ibadan, South-western Nigeria, and African Journal of Microbiology Research. 2015; 9(20):1357-1365.

[11] Atici T, Ahiska S, Altinda A, Aydin D (2008). Ecological effects of some heavy metals (Cd, Pb, Hg, Cr) pollution of phytoplanktonic algae and zooplanktonic organisms in Sarıyar Dam Reservoir in Turkey Afr. J. Biotech. 2008; 7:1972-1977.

[12] Okonko,I.O; Adejoje, O.D; Ogunnusi, T.A; Fajobi, E; Shittu, O.B. Microbiological and physicochemical analysis of different water samples used for domestic purposes in Abeokuta and Ojota, Lagos Nigeria. African J. Biotechnol, 2008; 7(5): 6717-6721.

[13] Okereke VE, Ogwo PA, Okoronkwo CU, Udensi EA. Evaluation of the Physicochemical and Heavy Metal Properties of Igwi-Stream in Abia State University, Uturu, Abia State, Nigeria. IOSR Journal of Environmental Science, Toxicology and Food Technology (IOSR-JESTFT). 2014; 8(7): 54-57.

[14] World Health Organization (WHO). (2011) Guidelines for drinking water quality (4th Ed.), Acceptability aspects: taste, odour and appearance. Geneva, 1-294.

[15] Ayoko A. Exploratory Multivariate modeling and prediction of the physicochemical properties of surface water and ground water. Journal of Hydro-environment. 2007; 336:115- 124.

[16] Mgbemena NM, Okwunodulu FU. Physicochemical and microbiological assessment of borehole waters inUmudike, Ikwuano L. G. A., Abia State, Nigeria. Advances in Applied Science Research. 2015; 6(4):210-214.

[17] Sammori T, Zulkifli Y, Baharuddin K, Shoji N,Makoto T. Suspended solids discharged from small forested basin in humid tropics. Hydro. Proc. 2014; 18 (4): 721 - 738.

[18] Khare R,Khare S. Physico-chemical analysis of Ganga Water, Asian journal of biochemical and pharmaceutical Research. 2011; 1(2).

[19] Sunday OE,Innocent CM. Physicochemical and Microbiological analysis of water bodies in Uturu, Abia State Nigeria Shanbehzadeh, S, Dastjerdi MV,Hassanzadeh AK. (2014). Heavy Metals in Water and Sediment: A Case Study of Tembi River. Journal of Environmental Science and Public Health. 2012; 1-5.

[20] Shally SC, Ajay K, Hiramoni D, Mukutamoni D, Chinmoy B, Aniruddha S,Parag D. Preliminary Physicochemical and Microbiological Analysis of Bahini River Water of Guwahati, Assam, India. International Journal of Current Microbiology and Applied Sciences. 2016; 5(2): 684-692.

[21] Godwill EA, Richard TA, Junior LCP. Marcellus: Physicochemical and microbial analysis of portable water sources in Enugu metropolis. Journal of Public Health and Epidemiology. 2015;7(3): 65-70.

[22] Rajini K, Roland P, John C,Vincent R. Microbiological and physicochemical analysis of drinking water in George Town. Nature and Science. 2010; 8(8): 261-265.

[23] Franson MA. Standard Methods for the Examination of Water and Waste Water.14th ed., APHA-AWWA- WPCF, APHA Publication office, 10115 18th St. NW, Washington DC. 1975; 20036: 185-237, 301-392, 405- 489.

[24] Tole MP,Shitsama JM. Concentrations of Heavy Metals in Water, Fish, and Sediments of the Winam Gulf, Lake Victoria, Kenya. Aquatic Ecosystem and Health Management Society. 2003. 
World Journal of Advanced Research and Reviews, 2021, 10(03), 392-398

[25] Wojtkowska M. Content of selected heavy metals in water and riverbed sediments of the Utrata River. Environment Protection Engineering. 2011; 37:55-62.

[26] Smith, A. H; Lingas, E. O and Rahman, M. (2000) Contamination of drinking water by arsenic in Bangladesh: a public health emergency. Bull World Health Organ 2020; 78(9):1093-1103. 